\title{
Framing Epizootic Diseases in Mass Media
}

\author{
Mădălina Bălășescu and Valentina Marinescu \\ Faculty of Sociology and Social Work, University of Bucharest, Romania
}

\section{Фрейминг на епизоотични заболявания в масмедиите}

Мадалина Болашеску и Валентина Маринеску

Факултет по социология и социална работа, Букурещки университет

\section{Author notes}

Valentina Marinescu ${ }^{(D)}$ https://orcid.org/0000-0002-9882-5902 is a Ph.D., professor at Faculty of Sociology and Social Work, University of Bucharest, Romania.

Mădălina Bălășescu (D) https://orcid.org/0000-0001-6174-612X is Ph.D. at Faculty of Journalism, University of Bucharest, Romania.

The authors declared no potential conflicts of interest concerning the authorship and publication of this article. The authors received no financial support for the publication of this article.

Correspondence concerning this article should be addressed to Valentina Marinescu, Faculty of Sociology and Social Work, University of Bucharest, 9 Schitu Măgureanu, Bucharest, 010181, Romania. E-mail: valentina.marinescu@sas.unibuc.ro

\section{Бележки за авторите}

Валентина Маринеску Dhttps://orcid.org/0000-0002-9882-5902 е доктор, професор във Факултета по социология и социална работа, Букурещки университет, Румъния.

Мадалина Болашеску https://orcid.org/0000-0001-6174-612X е доктор във Факултета по журналистика, Букурещки университет, Румъния.

Авторите декларират, че нямат финансова подкрепа и потенциален конфликт на интереси по отношение на публикуването на тази статия.

Кореспонденцията, свързана със статията трябва да бъде адресирана до Валентина Маринеску, Факултет по социология и социална работа, Букурещки 
университет, 9 Schitu Măgureanu, 010181 Букурещ, Румъния. Електронна поща: valentina.marinescu@sas.unibuc.ro 


\begin{abstract}
This article deals with general and specific aspects of how Romanian media covered the African swine flu crisis between 2014 and 2018. The analysis was mainly based on the available ground of media framing theory. The mediatic tone of reporting the African swine flu predicament complies with the pre-crisis, crisis, and post-crisis stages, as identified in the literature. Concerning the Romanian media approach on the African swine flu subject, the economic consequences and the mediatic leadership frames proved to be strongly related to similar inter-human and zoonotic diseases. The Romanian coverage of epizootics' main frames indicates a detached approach to the subject with exciting variations regarding the connections between information units and the general norms of mediatic content. This research suggests a few remarkable aspects that hint at current changes in the journalistic paradigm and the need to acknowledge crisis communication's significance when dealing with epizootic diseases.
\end{abstract}

Keywords: African swine flu, media, risk, crisis communication, framing

\title{
Резюме
}

Тази статия се занимава с общи и специфични аспекти на това как румънските медии отразяват африканската криза на свинския грип в периода между 2014 и 2018 г. Анализът се основава на теорията за медийния фрейминг. Оказва се, че медиативният тон на докладване на африканския свински грип отговаря на етапите отпреди кризата, през самата криза и след кризата, както е посочено в литературата. Що се отнася до подхода на румънските медии по темата за африканския свински грип, икономическите последици и медиативните рамки на лидерство се оказа, че те са силно свързани с подобни междучовешки и зоонозни заболявания. Румънският обхват на основните рамки на епизоотията показва отделен подход към темата с вълнуващи вариации по отношение на връзките между информационните единици и общите норми на медиативното съдържание. Изследването внушава няколко забележими аспекта, които подчертават текущите промени в журналистическата парадигма и необходимостта да се открои значението на комуникацията при кризи, при справяне с епизоотични заболявания. 
Ключови думи: африкански свински грип, медии, риск, кризисна комуникация, рамкиране

ARTICLE INFO:

Original Article

Received: 16, 06.2020

Revised: 21, 06.2020

Accepted: 30, 06.2020 


\section{Framing Epizootic Diseases in Mass Media}

The concern with mass-media coverage of public health crises has been largely debated in the literature. In this respect, Glik (2007), Yu, Frolich, Fougner, and Ren (2011) show that media has become a key-platform in public communication during a public health crisis. Moreover, journalists commit themselves to efficiently communicating the risks involved in epidemics in the sense of finding comprehensive ways of presenting a complex material in which confusion and uncertainty dwell, thus making it difficult to be understood by a typical audience (Calman, Bennett and Corns, 1999; Berry, 2004).

From the mass-media perspective, to become newsworthy, as Moeller (1999) suggests, a disease has to match some requirements known as the "Ebola standards," defined by sensationalism, prominence, novelty, controversy, emotional appeal, significance, and proximity. Generally speaking, media are interested in epidemics issues and cover the crises related to human public health and zoonotic nature (Poulson, 1996; Peters et al., 2006; Roche and Muskavitch, 2003).

African swine flu is one of the diseases which did not gain significant media attention. African swine flu is an epizootic disease (e.g., an animal disease that does not spread to humans). As a contagious and hemorrhagic disease, it only affects (domestic and wild) swine (World Organisation for Animal Health, 2018). It presents complex epidemiology, which varies depending on the environment, the type of production systems, and the presence or absence of wild boars (World Organisation for Animal Health, 2018).

In Romania, the African swine flu epidemic was detected in 2017 (terBeek, 2017) and spread rapidly afterward. Overall, more than 500,000 domestic swine were sacrificed. The main characteristic of the African swine flu spread in Romania was how the domestic swine were raised. In individual peasant households (defined by limited agrarian management practices and almost complete lack of biosecurity levels), which are common in Romania, swine are raised for family consumption, the investment in infrastructure is minimal, the animals are fed leftovers, and sometimes the pigs are allowed to move freely during the day.

Although it is an epizootic disease, the African swine flu's social and economic impact is considerable. The African swine flu problem has been directly related to losses in the local food industry and negative social impact, the issue is covered in Romanian and international media (Bălășescu, 2019). This article identifies and analyses the specific aspects of how 
Romanian media covered the African swine flu epidemic between January $1^{\text {st }} 2014$, and December $31^{\text {st }} 2018$.

Any public health crisis leads to complex, non-linear interactions between the social, political, or psychological systems (Seeger and Reynolds, 2008). Within an environment defined by swift changes, communicating epidemics issues raises many challenges for the public and media alike (Coombs, 1999). As Roche and Muskavitch (2003) mention, a substantial part of what people find happens through mass media. Moreover, people concerned about prevention explore non-medical sources of information like mass-media (Lewis et al., 2012; Ramirez et al., 2013).

Numerous studies link epidemics to significant public health crises (Fink, 1986; Mitroff, 1994; Birch, 1994; Mitchell, 1986; Woodcock, 1994; Ungar, 1998). In her seminal study on the phases of the onset and spread of infectious disease, Ungar (1998) indicates the three stages of an epidemic: the alarm, dominated by the fearful claim-making; the mixed messages, marked by continuous threat and moderated by assuring elements; hot crisis and containment, representing the efforts to undo the most frightful elements of pandemic interpretive packages.

The present study analyses the media coverage of an epizootic disease (African swine flu), and it is primarily based on the general theory of media framing (Entman, 1993, 2007; Iyengar, 1994; Semetko and Walkenburg, 2000). Throughout the last decades, some studies developed special categories of frames dedicated to public health crises (Shih, Wijay, and Brossard, 2008; Bowe, Ohita, Terracina-Hartman, and Chao, 2014; Birnbrauer, Frohlich, and Treise, 2015; Liu and Pennington-Gray, 2015; Harris, 2016). As for the modality in which the media have outlined infectious diseases, the literature indicates that dominant frames associated with health issues vary broadly, spanning a wide range of actions, from social responsibility to conflict, medical findings, causes, prevention, and treatment (Andsager and Powers, 1999; De Vreese, Peter, and Semetko, 2001; Park and Reber, 2010; Viswanath and Emmons, 2006).

However, as some studies show (Powers and Gong, 2008; Wallis and Nerlich, 2005), the media haphazardly examines epidemics, these discrepancies being politically, economically, socially, and geographically conditioned. Moreover, in the case of a unique epidemic, it is not just the geography or the social and political context that can influence the 
means of framing of the disease in the media, but also the type of media that covers the subject (Gao, Zhang, and Sadri, 2011; Lee and Basnyat, 2013).

Many contemporary studies focused on media coverage concerning subjects like agriculture and food safety. It is also the case of courses dedicated to biotechnology, E. Coli infection, or the aspect in which the media have presented a series of foodborne or zoonotic diseases (Smith, Young, and Gibson, 1998; Nisbet and Lewenstein, 2001; Ten Eyck, 2000; Fisher et al., 1994). The media's interest toward these subjects is rigorously linked to the fact that when it comes to health crises that originate in foodborne or zoonotic diseases, the audience feels just as insecure as they would in the case of human-to-human transmission. Moreover, information linked to aspects of the agricultural or zoonotic crises are much more ambiguous (Mitchell, Bakewell, Jackson, and Heslin, 2015). Analyses on the media coverage of the diseases demonstrate that newspapers, in particular, did not fully exhibit the risks associated with them (Dudo, Dahlstrom, and Brossard, 2007; Roche and Muskavitch, 2003).

The methods used by the media to cover public health crises differ tremendously according to geopolitical factors (Paulson, 1996). To the best of our knowledge, media coverage of epizootics has been less studied, and in the case of African swine flu, such research is absent. We assumed that the procedure used by the Romanian media to present the epizootic was a negative one. A series of research on media coverage of health issues revealed that adopting a negative tone is expected in news broadcasting (Brodie, Brady, and Altman, 1998; Marcantoni et al., 2011). The negative news on health either implies a vocabulary blaming governors for the crisis (Kuttschreuter el al, 2011) or refers to a purely sensationalist approach (Carslaw, 2008). Thus, both inter-human and zoonotic epidemics were frequently studied from the perspective of event dramatization (Grabe, Zhou, and Barnett, 2010; Vettehen et al., 2005; Dudo, Dahlstrom, and Brossard, 2007) and we assume this would also apply in the case of an epizootic.

Another direction for this research is driven by the lack of compelling results concerning the homogeneity of the textual information and the formal characteristics of media coverage norms (images, language, personal narratives, or visual effects) (Klemm, Das, and Hartmann, 2016). The analysis is crucial because of the two groups of textual elements that influence perceptions of risk related to information processing and the subsequent assessment of the situation (Visschers, Meertens, Passchier, and De Vries, 2008; Zillmann, 2006).

\section{Method and materials}

Проблеми на постмодерността / Postmodernism Problems Vol. 10, No. 2, 2020, ISSN: 1314-3700, https://pmpjournal.org https://doi.org/10.46324/PMP2002177 
Given the absence of previous studies on the African swine flu crisis's media framing, we chose an inductive method for investigating the frames related to the topic. This approach can capture the diversity of frames that can be determined in the evaluated sample of articles (Semetko and Valkenburg, 2000).

We asked the following research questions:

RQ1: How did the Romanian media cover the African swine flu crisis of 2018? What were the peculiarities of this media approach?

RQ2: What does the relationship between the textual information and the articles' formal features reveal the specifics of media coverage of the African swine flu crisis?

The study sample comprised 450 articles, including all the search results for the online articles on swine flu in Romania, published between January $1^{\text {st }} 2014$ and December $31^{\text {st }}$ 2018. When investigating Romanian mass-media, we were not granted access to LexisNexis Academic, as it was the case for other studies (Roche, 2002; Hellsten and Nerlich, 2010; Shan et al., 2013; Rim, Hong Ha and Kiousis, 2014). For this reason, similarly to other studies (Birnbauer, Frohlich, and Treise, 2015; Meisner, 2017), we used the Google search engine by introducing keywords (in Romanian) like "pigs," "swine," "swine flu," "swine flu epidemic," "African swine flu," and "pig disease." We analyzed the articles identified in the first 15 Google Search pages for every mentioned keyword. The selected texts (450) were published in online newspapers, news aggregator websites, and television station websites. The articles were interpreted using a two-part analysis grid, and the SPSS software package was used for descriptive and inferential statistics.

\section{Results}

Most of the articles on the African swine flu have been published right after the 2018 outbreak, in August (40\%) and September (28.8\%), as the amount began to decline in October (11.2\%) massively, and the following months. Our data reveal that Romanian media reports on the African swine flu crisis would relatively fit the pattern of the three stages of crisis (precrisis, crisis, post-crisis) detected by the literature (Birch, 1994; Mitchell, 1986; Woodcock, 1994).

The preponderance of articles on African swine flu was posted on television station websites and news-only websites, distantly followed by information platforms. However, the media coverage during the African swine flu crisis was unbalanced. The information platforms and television station websites were the only ones to cover the entire analyzed 
interval (January 2014 - December 2018). The highest number of articles being reached in August 2018 (37\% published through information platforms, and 33.8\% through television station websites).

Almost half of the articles issued on the African swine flu crisis were medium-size informative texts (over 20 texts) lines. Nearly a quarter were news reports providing necessary details. Interviews and opinion units were the least adopted genres for covering the subject.

The evolution of the media coverage in the African swine flu crisis was incongruous throughout various articles. Thus, all the news accounts featured on radio station websites tackling the African swine flu problem were released in September 2018, while half of the opinion pieces were published in October 2018. Medium-size informative texts and news were the only media genres used consistently throughout the considered time frame. A total of $72.3 \%$ of the selected articles contained one or more photographs or videos that featured animals. Most of the pictures featuring animals were of domestic pigs and domestic or wild swine shown alive. Only $13.9 \%$ of the photographs featuring animals were displaying them as dead or slaughtered. Wild swine were barely illustrated throughout the investigated articles.

In the majority of cases, the African swine flu crisis was not deemed as unfavorable. Thus, a quarter of the examined articles referred to the disease as "African swine flu," while in one-fifth of the total sample of articles, it was called "swine flu." The use of highly emotional words with negative impact was sporadic throughout the chosen time frame. Only $0.3 \%$ of the articles attributed the term "deadly disease" and $0.5 \%$ compared the disease to a "scourge." Most of the references to other associated words occurred in August and September 2018, as the African swine flu was mentioned as a "virus," an "outbreak," and an "epidemic."

Over one-sixth of the considered articles indicated the Romanian National Sanitary Veterinary and Food Safety Authority (NSVFSA) as a source, and one-ninth cited the county Sanitary Veterinary and Food Safety Directorate (SVFSD). Other sources of information concerning the African swine flu outbreaks were traditional media, such as newspapers, television shows, or ministers. Half of the inspected articles cited people, documents, and institutions. An intriguing month was October 2018, when a considerable amount of papers were. The main "definers of the situation" (Miller, 1993) in the case of the African swine flu were a minister, the county SVFSD officials, politicians, local administration officials, the 
liable ministries - through their decisions, the local administration - through the issued documents, and the Romanian state or the European Union - through active laws.

The causes and spread of the African swine flu were discussed in $23.1 \%$ of the articles. The most mentioned causes of the outbreaks were linked to medical and veterinary implications, animal movement patterns, the lack of control measures from state or local authorities, and the ineffective or untimely interventions.

The repercussions of the onset and spread of the African swine flu were presented in $75.5 \%$ of the sample articles. The most mentioned causes were deceased animals suspected of carrying the disease, the spread of the virus, the socio-economical kind, strictly social, strictly medical, and veterinary.

The risks associated with the African swine flu occurrence and escalations were indicated in $56.2 \%$ of the articles. After data, the most frequently mentioned risks were the virus's spread, the economic kind, strictly medical or veterinary, strictly epizootic, and exclusively on agriculture.

An amount of $65.5 \%$ of the articles mentioned who was responsible for the African swine flu outbreaks. The journalists assigned the African swine flu outbreaks responsibilities as follows: medical and veterinary officials; the virus itself; Romanian central authorities; the liable ministries - including, but not limited to, the Ministry of Agriculture; politicians in general; domestic swine; wild swine.

The factors which facilitated the onset and spread of the African swine flu were mentioned in $42.1 \%$ of the chosen articles. The most common elements were the biological kind, the natural movement patterns of the (mostly wild) animals, the specificity of the disease - viral and contagious, incorrect or incomplete control and prevention measures, and the reckless behaviour of ordinary people.

In almost half of the articles (49.4\%), the journalists discussed the barriers to slowdown or stopped the virus spread. The most recurring obstacles in the way of African swine flu were: animal slaughter, the measures taken by the central authorities, eradication of the African swine flu outbreaks, and specific control measures in the affected areas.

The tone used throughout the articles (positive, negative, or neutral) varied over time. The only month in which the African swine flu media coverage in Romania conveyed an optimistic tone was when the crisis started when $50.1 \%$ of the articles embraced it. In all the other months, the overall tone was either negative or neutral. 
The data set demonstrates that most of the articles used logical arguments in the months following the crisis. It was not until October 2018 that emotional arguments overtook the logical ones in terms of incidence.

Data analysis shows that journalists have turned to scientific language only in the first months following the crisis in opting for a scientific or common language. In all the remaining months, the common language was predominant.

Applying the pattern proposed by Ungar (1998) to the current data set, the Romanian media behaved differently at the start of the African swine flu crisis, in the "sounding the alarm" phase. The predominant use of scientific language, positive tone, and logical arguments, in this precise instance, contradicts Vasterman and Ruigrok's (2013) conclusions, which state that alarmist and pessimistic tones prevail in the first stage of a public health crisis covered by the media.

As for the relation between the textual information and the African swine flu crisis's formal characteristics, our logistic regression models allow us to identify the inflection points. Thus, regarding the Romanian media coverage of the risks associated with the onset and spread of the African swine flu, the use of common language, the presence of animals in the photos and videos embedded in the articles, the known identity of the people featured in the images or footage associated with the article, the use of logical arguments and a positive tone mattered the most. Concerning the articles related to the African swine flu etiology, the elements that counted were the juxtaposition of text and images or videos featuring animals, the presence of known people in the photographs or footage associated with the article, the use of logical arguments, common language and negative tone. Images or videos of animals, a clear identity of the people seen in the images or videos, a positive tone, and the use of common language were the most significant media facets of the onset and spread of the African swine flu. The media units formulated in a common language, the visual content distributed alongside the text featuring animals, the people displayed in images or video having clear identities, and the use of negative tone and emotional arguments weighed the most in the case of articles investigating the response of the African swine flu crisis. The most valuable formal aspects regarding the articles mentioning the consequences of the African swine flu were the use of scientific language, positive tone, logical arguments, and the presence of animals in the visual content linked to the text. The use of a positive tone, 
common language, and visual content featuring animals were the most significant explanatory factors that specify the barriers to the African swine flu spread.

\section{Discussion}

As in the case of the H1N1 epidemic investigated by Lee (2014), our analysis observed the existence of specific frames which subordinate to the typology recommended by Iyengar (1994), most of the articles episodically framing the African swine flu crisis. Here we consider that: there was a precise location of the African swine flu outbreaks (more than half of the inspected articles), the main "definers of the situation" were the local authorities alongside the county sanitary veterinary directorates, and the actions were taken by the local officials were perceived as the main barriers against the spread of the virus.

The emphasis on the economic indicators in the African swine flu crisis's media construction makes its coverage somewhat similar to that used by USA media in framing the mad cow disease epidemic, prioritizing the national economy over human health (Ashlock, Cartmell, and Kelemen, 2006). The main frames associated with the African swine flu crisis, which were identified in our analysis, were similar to a certain extent to those observed by Luther and Zhou (2005) concerning the framing of SARS in Hong Kong and the USA. For Romania, we discern two media frames: economic consequences and leadership. Concerning the leadership frame, the media labels for the epidemic were: "African swine flu," "virus"; the article citing the NSVFSA, other media and/or a peasant as sources, mentioning the barriers and derived risks, and indicating the number of swine slaughtered or found dead having been affected by the disease.

In our research, we also isolated two frames comparable to those used by Bardhan (2001) who explained how the AIDS epidemic was presented as a medical and scientific concern, but also as a political and legal issue: In the articles which treated the African swine flu outbreaks as a medical and scientific matter, the disease was termed as a "virus" and/or an "epidemic", the source was the county Sanitary Veterinary and Food Safety Directorate (SVFSD) and/or a peasant (small farmer), a national or European legal framework regulating such diseases was mentioned, as well as the associated risks and the barriers against the further spread. Additionally, the condition was described as a "virus," the source was a minister and/or a farmer (commercial farm owner), the barriers against further spread were regularly mentioned, but also the derived risks along with the factors that facilitate the outbreaks, while indicating the number of swine slaughtered or found dead. 
The fact that the negative tone did not prevail contravenes the existing studies, which underline that, during an epidemic, mass-media favors negative information over-optimistic (Nelkin, 1995). Moreover, our results show an overwhelming number of neutral approaches to the African swine flu crisis, thus contradicting the results of Rowe, Frewer, and Sjoberg (2000), which pointed out that journalists present accidents and epidemics in a somewhat alarmist way.

The stress laid on negative elements belonging to the causes, consequences, factors, barriers and the responsibilities associated with the African swine flu crisis confirms the existing analyses that demonstrate that, during such an event (e.g. a crisis), the media has a predilection for exposing risks and unlikely, lively, dramatic, and recent events (Singer and Endreny, 1987; Soumerai, Ross-Degnan, and Kahn, 1992; Nelkin, 1995). However, unlike existing research (Abbasi, 1998; Bartlett, Sterne, and Egger, 2002), the analysis of the formal elements of the texts do not confirm the hypothesis of Bartlett, Sterne, and Egger (2002), which states that during a public health crisis, media select and deliver negative information rather than positive facts.

The minimum use of terms carrying a profoundly negative symbolism (such as "plague," "scourge," or "malady") implies the diminished role of a terminology meant to induce emotion in the instance of the Romanian media coverage of the African swine flu. Thus, our results are at variance with the thesis of Fung, Namkoong, and Brossard (2011), which asserts that, during a zoonotic epidemic, one of the main tendencies in media's description of the disease is the use of emotional vocabulary. From here and following the reasoning of Fung, Namkoong, and Brossard (2011), we can assert that it is plausible that this type of media discourse can weaken the perception of risk associated with African swine flu. Or, Romanian media did not present the African swine flu as a lethal threat, with irreversible health damage and uncontrollable outcomes.

Our data also pointed out fluctuations of the explanatory contribution of the formal characteristics to structuring a particular image for the African swine flu crisis. Therefore, visual elements (photographs of animals, pictures, or videos in which specific individuals' identity was disclosed) were typical for articles that exposed the risks and responsibilities related to the African swine flu. As for the media's language, when addressing the African swine flu crisis's consequences, journalists opted for the scientific one. Still, they switched to a common language when evaluating the derived risks and responsibilities. The barriers 
preventing the spread of the disease were communicated with a mostly negative tone. Concerning the consequences and risks associated with the epidemic, these were discussed using predominantly logical arguments. Simultaneously, inspirational ideas were mainly noticed in articles that talked about responsibility for spreading the virus.

\section{Conclusions}

As Reynolds and Seeger (2014) pointed out, mass communication is the prime source of public information during epidemics. In the event of a pandemic, mass-media work to amplify the risk (Kasperson, J., Kasperson, R. \& Pidgeon, 2003). Moreover, epidemics tend to obey newsworthiness criteria because they are mysterious, dramatic, and fast-spreading, imply a high number of deaths, and can generate political and economic catastrophes (Lee, 2008).

Infectious diseases are increasingly significant for scientists and the broader public (Woebeser, 2006). Also, until now, from the standpoint of the proximity between animal diseases and the agro-food industry (Ashlock, Cartmell, and Kelemen, 2006; Caplan, 2000; Miller, 1999), an increase in the negative impact of labeling the topic of animal-originated diseases as an industry crisis was noticed (Caplan, 2000; Miller, 1999).

In the case of the African swine flu, statistical data showed that between 2017 and 2019, the economic repercussions of the epizootic were considerable, swine meat exports collapsing by $41.3 \%$ between June 2017 and July 2018 (USDA - Foreign Agricultural Service, 2018). Around the same period, the production value in the swine sector (domestic pigs) dropped from 18\% (2017) to 16.7\% (2018) (Revista Patronatelor, 2019). No connection was made until now between the economic and social consequences of the African swine flu crisis and mass media presentation of an epizootic crisis.

Simultaneously, the Romanian media's depiction of the African swine flu outbreaks is under the distinction made by Thys (2019), who separated "carriers" by the two possible circumstances: inter-human transmitted diseases and zoonotic infections. By exposing deceased or slaughtered animals in the visual content annexed to the article, the emphasis is on the medical and veterinary causes, risks, and consequences of the disease's onset and spread. The persistent occurrence of biological factors mentioned throughout the African swine flu media coverage disclosing the epidemic pathogens' potential indicates the relation between the "carrier" and its victim. Thus the animals are no longer just "carriers" but also victims of the virus (Thys, 2019). 
The mentioning of natural animal migration as the second type of factors that allowed the virus spread in Romania is directly linked to the application of the zoonosis control measures that are akin to those performed on human migration, or, for instance, the security fences raised across state borders to prevent the natural movement of wild boars (Keck, 2019).

The structural ambiguity in what concerns the media coverage of the crisis related to agriculture partly originates in the professionals' work in this field. Studies conducted by White and Rutherford (2009) and King, Cartmell, and Sitton (2006) signal that most journalists show low levels of agricultural literacy, thus influencing how they present specific information. A possible outcome of this state of affairs (yet to be explored by existing literature) is the influence that this low level of agricultural literacy has on the biased or incomplete reports on the agricultural sector. Therefore, the research conducted by Peters et al. (2006) and Roche and Muskavitch (2003) concludes that there have been distortions and incorrect information on the subject of public health issues in the media. Considering the as a result of this analysis, given the significant importance of the "official definers of the situation" (government, ministries, central and local agencies), as well as the general use of official sources (central and local), weaknesses concerning the media coverage of an epizootic may be at least minimized.

This study's primary limitation is that it is focused on a sample assembled entirely of Romanian online media articles. A particular element of the African swine flu in Romania is indeed the number of deaths. The majority of these deaths were reported among domestic swine, wild boars being less affected (Cwynar, Stojkov, and Wlazlak, 2019). This aspect differs from other contaminated countries. Given the focus of the analysis on Romanian media, even though the African swine flu crisis had spread over several Eastern Europe (Poland, Lithuania, Latvia, Bulgaria), our analysis cannot be generalized for a larger geographical and cultural area.

Despite the mentioned limitations, the study provides some exceedingly significant elements related to current transformations in mass media and journalism. More precisely, the main frames identified when observing the media coverage of epizootics (economic prospects, leadership, medical and scientific aspects, political and legal issues) suggest a relatively relaxed approach. The variations of the connections between the textual information 
and the formal characteristics of media coverage may indicate essential elements to be considered in further evaluations of animal-related crises and risk communication. 


\section{References}

Abbasi, K. (1998). Headlines: more perilous than pills? British Medical Journal, 316(7124), 82-97.

Andsager, J., \& Powers, A. (1999). Social or economic concerns: How newspapers and women's magazines framed breast cancer in the 1990s. Journalism \& Mass Communication Quarterly, 76, 531-550.

Ashlock, M. A., Cartmell, D. D., \& Kelemen, D. B. (2006). The cow that stole Christmas: Framing the first U.S. mad cow crisis. Journal of Applied Communications, 90 (2), 2946. https://doi.org/10.4148/1051-0834.1282

Bălășescu, M. (2019). La peste porcine sur l'agenda des médias roumains. Étude de cas: Ziare.com. In V. Marinescu \& D. Rovenţa-Frumuşani (Eds.), Santé et nutrition dans les médias actuels (pp. 134-146). Ars Docendi.

Bardhan, N. (2001). Transnational AIDS-HIV news narratives: A critical exploration of overarching frames. Mass Communication \& Society, 4(3), 283-309. https://doi.org/10.1207/S15327825MCS0403_03

Bartlett, C., Sterne, J. \& Egger, M. (2002). What is newsworthy? British Medical Journal 325(7355), 81-84. doi: 10.1136/bmj.325.7355.81.

Berry, D. (2004). Risk, Communication \& Health Psychology (First Ed.). Open University Press.

Birch, J. (1994). New factors in crisis planning and response. Public Relations Quarterly, 39(4), 31-34.

Birnbrauer, K., Frohlich, D. O., \& Treise, D. (2015). Inconsistencies in reporting risk information: a pilot analysis of online news coverage of West Nile Virus. Global Health Promotion. doi: 10.1177/1757975915594603

Bowe, B. J., Oshita, T., Terracina-Hartman, C., \& Chao, W.-C. (2014). Framing of climate change in newspaper coverage of the East Anglia e-mail scandal. Public Understanding of Science, 23(2), 157-169. doi: 10.1177/0963662512449949

Brodie, M., Brady L. \&Altman D. (1998). Media coverage of managed care: Is there a negative bias? Health Affairs, 17(1), 9-25. https://doi.org/10.1377/hlthaff.17.1.9 
Calman, K. C., Bennett, P. G., \& Corns, D. G. (1999). Risks to health: some key issues in management, regulation, and communication. Health, Risk \& Society, 1(1), 107-116. https://doi.org/10.1080/13698579908407010

Caplan, P. (2000). Eating British beef with confidence: A consideration of consumers' responses to BSE in Britain. In P. Caplan (Ed.), Risk revisited (pp. 1-29). University of Michigan Press.

Carslaw, N. (2008). Communicating risks linked to food - the media's role. Trends in Food Sciences \& Technology 19, S14-S17. https://doi.org/10.1016/j.tifs.2008.06.007

Coombs, T. W. (2007). Ongoing crisis communication: Planning, managing, and responding. Thousand Oaks. SAGE Publications.

Coombs, T. W. (1999). Ongoing crisis communication: Planning, managing, and responding. Thousand Oaks. SAGE Publications.

Cwynar, P., Stojkov, J., \& Wlazlak, K. (2019). African swine fever status in Europe. Viruses, $11(4)$.

De Vreese, C. H., Peter, J., \& Semetko, H. A. (2001). Framing politics at the launch of the Euro: A cross-national comparative study of frames in the news. Political Communication, 18, 107-122. https://doi.org/10.1080/105846001750322934

Dudo, A. D., Dahlstrom, M. F., \& Brossard, D. (2007). Reporting a potential pandemic: A risk-related assessment of avian influenza coverage in US newspapers. Science Communication, 28(4), 429-454. Doi:10.1177/1075547007302211

Entman, R. M. (1993). Framing: Toward clarification of a fractured paradigm. Journal of Communication, 43(4), 51-58. https://doi.org/10.1111/j.1460-2466.1993.tb01304.x

Entman, R. M. (2007). Framing bias: Media in the distribution of power. Journal of Communication, 57(1), 163-173. https://doi.org/10.1111/j.1460-2466.2006.00336.

Fink, S. (1986). Crisis management: Planning for the inevitable. Amazon.

Fisher, A., King, R., Epp, D. J., Brown, J. L., \& Maretzki, A. N. (1994). Evaluating alternatives for communicating about food risk. Journal of Applied Communication, $78(2), 1-11$.

Fung, T. K., Namkoong, K., \& Brossard, D. (2011). Media, social proximity, and risk: A comparative analysis of newspaper coverage of avian flu in Hong Kong and the United States. Journal of Health Communication, 16, 889-907. doi.org/10.1080/10810730.2011.561913 
Gao, F., Zhang, M., \& Sadri, S. (2011). Newspapers use more sources compared to health blogs in H1N1/swine flu coverage. Newspaper Research Journal, 32(2), 89-96.

Glik, D. C. (2007). Risk communication for public health emergencies. Annual Review of Public Health, 28, 33-54. doi: 10.1146/annurev.publhealth.28.021406.144123.

Grabe, M. E., Zhou, S., \& Barnett, B. (2010, November 10). Explicating sensationalism in television news: Content and the bells and whistles of form explicating sensationalism in television news. Content and the Bells and Whistles of Form, 37-41.

Harris, P. (2016). Achoo! Three major us newspapers reporting on the flu before and after hln1. [Masters Theses, James Madison University]. http://commons.lib.jmu.edu/master201019/91

Hellsten, I., \& Nerlich, B. (2010). Bird flu hype: the spread of a disease outbreak through the media and Internet discussion groups. Journal of Language and Politics, 9(3), 393408. DOI: $10.1075 / \mathrm{jlp} \cdot 9.3 .03 \mathrm{hel}$

Herek, G. M., Capitanio, J. P., \& Widaman, K. F. (2003). Stigma, social risk, and health policy: Public attitudes toward HIV surveillance policies and the social construction of illness. Health Psychology, 22(5), 533-540. doi.org/10.1037/0278-6133.22.5.533

Hopkins, V. \& Terazono, E. (2019). African swine fever drives up European pork prices. Steep rise this year could mean more expensive bacon in Spain, Germany, and Poland. Financial Times.

https://www.ft.com/content/5d6a2c8a-eab5-11e9-85f4-d00e5018f061

Iyengar, S. (1994). Is anyone responsible? How television frames political issues. University of Chicago Press.

Jurado, C., Martínez-Avilés, M., De La Torre, A., Štukelj, M., de Carvalho Ferreira, H. C., Cerioli, M., Sánchez-Vizcaíno, J.M. \& Bellini, S. (2018). Relevant measures to prevent the spread of African swine fever in the European Union domestic pig sector. Frontiers in veterinary science, 5(77). https://doi.org/10.3389/fvets.2018.00077

Kasperson, J. X., Kasperson, R. E., \& Pidgeon, N. (2003). The social amplification of risk: Assessing fifteen years of research and theory. In N. Pidgeon, R. E. Kasperson, \& P. Slovic (Eds.), The social amplification of risk (pp. 13-46). Cambridge University Press.

Keck, F. (2019). Postscript: epidemic villains and the ecologies of the nuisance. In C. Lynteris (Ed.), Framing animals as epidemic villains (pp. 229-236). Palgrave Macmillan. 
King, J.M., Cartmell, D.D., and Sitton, S. (2006). Newspaper coverage of the bovine spongiform encephalopathy outbreak in the United States: A content analysis. Journal of Applied Communications, 90(3), 33-47.

Klemm, C., Das, E., \& Hartmann, T. (2016). Swine flu and hype: a systematic review of media dramatization of the H1N1 influenza pandemic. Journal of Risk Research, 19(1), 1-20. https://doi.org/10.1080/13669877.2014.923029

Kuttschreuter, M., Guttering, J. M. \& de Hond, M. (2011). Framing and tone-of-voice of disaster media cover-age: The aftermath of the Enschede fireworks disaster in the Netherlands. Health Risk \& Society, 13(3), 201-220. https://doi.org/10.1080/13698575.2011.558620

Lee, A. Y. L. (2008). Internet freedom and online crisis responding: The role of news web sites in the SARS epidemic. In J. H. Powers \& X. Xiao (Eds.), The social construction of SARS. Studies of a health communication crisis (pp. 69-90). John Benjamins Publishing.

Lee, S. T. (2014). Predictors of H1N1 influenza pandemic news coverage: explicating the relationships between framing and news release selection. International Journal of Strategic Communication, 8(4), 294-310. doi.org/10.1080/1553118X.2014.913596

Lee, S. T., \& Basnyat, I. (2013). From press release to news: mapping the framing of the 2009 H1N1. An influenza pandemic. Health Communication, 28(2), 119-132. DOI: $10.1080 / 10410236.2012 .658550$

Lewis, N. et al. (2012). Seeking cancer-related information from media and family/friends increases fruit and vegetable consumption among cancer patients. Health Communication, 27(4), 380-388. doi.org/10.1080/10410236.2011.586990

Liu, B. F. (2010). Distinguishing how elite newspapers and list blogs cover crises: Insights for managing crises online. Public Relations Review, 36(1), 28-34. DOI: 10.1016/j.pubrev.2009.10.006

Liu, B., \& Pennington-Gray, L. (2015). Do bed bugs bite the hospitality industry? A framing analysis of bed bug news coverage. Tourism Management, 48, 33-42. doi.org/10.1016/j.tourman.2014.10.020

Luther, C. A., \& Zhou, X. (2005). Within the boundaries of politics: News framing of SARS in China and the United States. Journalism \& Mass Communication Quarterly, 82(4), 857-872. doi.org/10.1177/107769900508200407 
Marcantoni, C., Bressanelli, M., Orizio, G. \& Gelatti, U. (2011). Health on the front page: A content analysis of the main Italian newspapers in two months of 2009. Annali di igiene: medicina preventiva e di comunita, 23(2), 115-124.

Meisner, C. (2017). When product loss minimizes product harm: The reframed narrative of bluebell creameries' 2015 listeriotic crisis. https://repository.tcu.edu/handle/116099117/19822

Miller, D. (1993). Official sources and primary definition: the case of Northern Ireland. Media, Culture \& Society, 15(3), 385-406. https://doi.org/10.1177/016344393015003004

Miller, D. (1999). Risk, science, and policy: definitional struggles, information management, the media, and BSE. Social Science \& Medicine, 49(9), 1239-1255. https://doi.org/10.1016/S0277-9536(99)00163-X

Mitchell, T. H. (1986). Coping with a corporate crisis. Canadian Business Review, 13, 17-20.

Mitchell, V. W. et al. (2015). How to message framing affects consumer attitudes in food crises. British Food Journal, 117, 2200-2211. doi.org/10.1108/BFJ-01-2015-0015

Mitroff, I.A. (1994). Crisis management and environmentalism: A natural fit. California Management Review, 36(2), 101-113. https://doi.org/10.2307/41165747

Moeller, S. D. (2002). Compassion fatigue: How the media sell disease, famine, war, and death. Routledge.

Nelkin, D. (1995). Selling science: how the press covers science and technology (revised edition). W.H. Freeman.

Nisbet, M., \& Lewenstein, B. V. (2001). A comparison of U.S. media coverage of Biotechnology with public perceptions of Genetic Engineering 1995-1999. [Conference presentation]. 2001 International public of science and technology conference. Geneva, Switzerland.

Park, H., \& Reber, B. H. (2010). Using public relations to promote health: A framing analysis of public relations strategies among health associations. Journal of Health Communication, 15, 39-54. DOI: 10.1080/10810730903460534

Peters, H. P., et al. (2008). Interactions with the mass media. Policy forum: Interactions with mass media. Science, 321(5886), 204-205. doi.org/10.1126/science.1157780 
Pig33 (2019, October 16). EU: ASF outbreaks in domestic pigs increase. https://www.pig333.com/latest_swine_news/eu-asf-outbreaks-in-domestic-pigsincrease_15400/

Poulsen, J. (1996). When journalism loses its senses: On mad cow disease and ritual sacrifice. Nordicom Review, 17, 3-9.

Powers, J. H., \& Gong, G. (2008). Hong Kong's multiple constructions of Sars'. In J. H. Powers \& X. Xiao (Eds.), The social construction of SARS: Studies of a health communication crisis, Vol. 30, (pp. 17-31). John Benjamins Publishing.

Ramírez, A. S., Freres, D., Martinez, L. S., Lewis, N., Bourgoin, A., Kelly, B. J., Lee, C. J., Nagler R., Schwartz, J.S. \& Hornik, R. C. (2013). Information seeking from media and family/friends increases the likelihood of engaging in healthy lifestyle behaviors. Journal of Health Communication, 18(5), 527-542.

doi.org/10.1080/10810730.2012.743632

Revista Patronatelor (2019, July, 26). ANALIZĂ Paradox în agricultură: Producția crește, dar importurile de mâncare ating cote record. Cum este posibil? [ANALYSIS A paradox in agriculture: as production grows, food imports reach record highs]. https://www.revista-patronatelor.ro/analiza-paradox-in-agricultura-productia-crestedar-importurile-de-mancare-ating-cote-record-cum-este-posibil/

Reynolds, B., \& Seeger, M. W. CDC. (2014). Crisis+ emergency risk communication. 2014 edition. Publication ID 221793. Centers for disease control and prevention. https://emergency.cdc.gov/cerc/resources/pdf/cerc_2014edition.pdf

Rim, H., Hong Ha, J., \& Kiousis, S. (2014). The evidence of compelling arguments in agenda building: Relationships among public information subsidies, media coverage, and risk perceptions during a pandemic outbreak. Journal of Communication Management, 18(1), 101-116. https://doi.org/10.1108/JCOM-05-2012-0044

Roche, J. P. (2002). Print media coverage of risk-risk tradeoffs associated with West Nile encephalitis and pesticide spraying. Journal of Urban Health, 79(4). doi: 10.1093/jurban/79.4.482

Roche, J. P., \& Muskavitch, M. A. (2003). Limited precision in print media communication of West Nile virus risks. Science Communication, 24(3), 353-365. https://doi.org/10.1177/1075547002250300 
Rowe, G., Frewer, L., \& Sjoberg, L. (2000). Newspaper reporting of hazards in the UK and Sweden. Public Understanding Science, 9(1), 59-78. DOI: 10.1088/0963-6625/9/1/304

Seeger, M. W., \& Reynolds, B. (2008). Crisis communication and public health: Integrated approaches and new imperatives. Crisis communication and public health; 1 .

Semetko, H., \& Valkenburg, P. (2000). Framing European politics: a content analysis of press and television news. Journal of Communication, 50(2), 93-109. doi.org/ 10.1111/j.1460-2466.2000.tb02843.x

Shan, L., Regan, Á., De Brún, A., Barnett, J., van der Sanden, M. C., Wall, P., \& McConnon, Á. (2014). Food crisis coverage by social and traditional media: A case study of the 2008 Irish dioxin crisis. Public Understanding of Science, 23(8), 911-928. https://doi.org/10.1177/0963662512472315

Singer, E. \& Endreny, P. (1987). Reporting hazards: their benefits and costs. Journal of Communication, 37(3), 10-26. https://doi.org/10.1111/j.1460-2466.1987.tb00991.x

Smith, A. P., Young, J. A., \& Gibson, J. (1998, July). How now, mad-cow? Consumer confidence and source credibility during the 1996 BSE scare. European Journal of Marketing, 33(11/12), 1107 - 1122.

Soumerai, S. B., Ross-Degnan, D. \& Kahn, J. S. (1992). Effects of professional and media warnings about the association between aspirin use in children and Reye's syndrome. Milbank Quarterly, 70, 155-182. http://hdl.handle.net/10822/852802

Target research effort on African swine fever (ASFORCE Project). Guidelines for the costeffective prevention and control of African swine fever (2015). http://asforce.org/sites/default/files/ASFORCE\%20Guidelines\%20ASF.pdf

Thys, S. (2019). Contesting the (super) natural origins of ebola in magenta, guinea: biomedical and popular approaches. In C. Lynteris (Ed.), Framing Animals as Epidemic Villains (pp. 177-210). Palgrave Macmillan.

Ten Eyck, T. A. (2000). The marginalization of food safety issues: An interpretative approach to mass media coverage. Journal of Applied Communication, 84(2), 29-47.

ter Beek, V. (2017, August 1). African Swine Fever has now reached Romania. Pig Progress, https://www.pigprogress.net/Health/Articles/2017/8/African-Swine-Fever-has-nowreached-Romania-165850E/ 
Ungar, S. (1998). Hot crises and media reassurance: A comparison of emerging diseases and Ebola Zaire. British Journal of Sociology. 36-56. doi.org/10.2307/591262

Vasterman, P. L., \& Ruigrok, N. (2013). Pandemic alarm in the Dutch media: Media coverage of the 2009 influenza. An (H1N1) pandemic and the role of the expert sources. European Journal of Communication, 28(4), 436-453. https://doi.org/10.1177/0267323113486235

Vettehen, P. H., Nuijten, K., \& Beentjes, J. (2005). News in an age of competition: The case of sensationalism in Dutch television news 1995-2001. Journal of Broadcasting \& Electronic Media, 49(3), 282-295. doi.org/10.1207/s15506878jobem4903_2

Visschers, V. H. M., Meertens, R. M., Passchier, W. F., \& De Vries, N. K. (2008). Audiovisual risk communication unraveled: effects on gut feelings and cognitive processes. Journal of Risk Research, 11(1-2), 207-221. https://www.tandfonline.com/doi/abs/10.1080/13669870801947954

Viswanath, K., \& Emmons, K. M. (2006). Message effects and social determinants of health: Its application to cancer disparities. Journal of Communication, 56(suppl_1), S238S264. https://doi.org/10.1111/j.1460-2466.2006.00292.x

USDA - Foreign Agricultural Service (2018, October 18). Romania: African swine fever continues to threaten Romanian hog farmers. https://apps.fas.usda.gov/newgainapi/api/report/downloadreportbyfilename?filename= African\%20Swine\%20Fever\%20Continues\%20to\%20Threaten\%20Romanian\%20Ho g\%20Farmers_Bucharest_Romania_10-15-2018.pdf

Wallis, P., \& Nerlich, B. (2005). Disease metaphors in new epidemics: the UK media framing of the 2003 SARS epidemic. Social Science \& Medicine, 60(11), 2629-2639. https://doi.org/10.1016/j.socscimed.2004.11.031

White, J. M., \& Rutherford, T. (2009). Impact of reporter work role identity on news story source selection: Implications for coverage of agricultural crises. Journal of Applied Communications, 93(3\&4).

https://cjdept.unm.edu/people/faculty/profile/docs/white_impact_of_reporter_beat_ass ignment_2009.pdf https://cjdept.unm.edu/people/faculty/profile/docs/white_impact_of_reporter_beat_ass ignment_2009.pdf

Woodcock, C. (1994, November 24). How to face a crisis with confidence. Marketing, 8-10. 
World Organization for Animal Health (2018). African swine fever.

https://www.oie.int/en/animal-health-in-the-world/animal-diseases/african-swinefever/

Yu, N., Frohlich, D. O., Fougner, J., \& Ren, L. (2011). Communicating a health epidemic: A risk assessment of the swine flu coverage in us newspapers. International Public Health Journal, 3(1 (Special Issue on "Health Risk Communication"). 63-76.

Zillmann, D. (2006). Exemplification effects in the promotion of safety and health. Journal of Communication, 56(s1), S221-S237.

doi.org/10.1111/j.1460-2466.2006.00291.x 